\title{
Ocena działań ustawodawcy na gruncie przepisów Kodeksu postępowania karnego dotyczących odszkodowania za niesłuszne stosowanie środków przymusu, ze szczególnym uwzględnieniem zabezpieczenia majątkowego
}

Ostatnimi czasy częstotliwość dokonywania nowelizacji Kodeksu postępowania karnego ${ }^{1}$ stała się, niebezpiecznie wręcz, wysoka. Mowa tu w szczególności o „wielkiej” nowelizacji k.p.k., na którą złożyły się dwie ustawy fundamentalnie zmieniające polskie postępowanie karne, które weszły w życie 1 lipca 2015 r. ${ }^{2}$ Podstawowym celem kompleksowej reformy postępowania karnego było przemodelowanie postępowania sądowego w kierunku większej kontradyktoryjności w jej klasycznym rozumieniu ${ }^{3}$. Ponadto należy wskazać na ostatnią nowelizację, która weszła w życie 15 kwietnia 2016 r. ${ }^{4}$ i, mówiąc ogólnie, w dużym stopniu stanowi zanegowanie wprowadzonych wcześniej zmian. Konsekwencją takich działań ustawodawcy stało się m.in. krótkotrwałe funkcjonowanie pewnych instytucji w zmienionej formie, które wskutek kolejnych nowelizacji przywracane są do wersji pierwotnej. Powoduje to bez wątpienia poczucie braku pewności prawa i wprowadza zamęt w stosowaniu przepisów procedury karnej.

Tematyka niniejszej pracy została zawężona do kwestii odszkodowania i zadośćuczynienia za niesłuszne stosowanie środków przymusu, w szczególności zabezpieczenia

1 Ustawa z dnia 6 czerwca 1997 r. - Kodeks postępowania karnego (Dz.U. nr 89 poz. 555). Warto zauważyć, że w okresie od września 1998 r. do sierpnia 2015 r. k.p.k. był zmieniany przez ok. 80 ustaw nowelizujących.

2 Mowa tu o następujących aktach normatywnych: ustawa z dnia 27 września 2013 r. o zmianie ustawy - Kodeks postępowania karnego oraz niektórych innych ustaw (Dz.U. poz. 1247) oraz ustawa z dnia 20 lutego 2015 r. o zmianie ustawy - Kodeks karny oraz niektórych innych ustaw (Dz.U. poz. 396), które weszły w życie 1 lipca 2015 r.

3 Szerzej: K. Dąbkiewicz, Kodeks postępowania karnego. Komentarz do zmian 2015, Warszawa 2015, s. 25-26.

4 Ustawa z dnia 11 marca 2016 r. o zmianie ustawy - Kodeks postępowania karnego oraz niektórych innych ustaw (Dz.U. poz. 437), która weszła w życie 15 kwietnia 2016 r. 
majątkowego. Pominięto zatem niezwykle szerokie zagadnienie odszkodowania za bezprawne pozbawienie wolności, z wyjątkiem sytuacji, kiedy nawiązanie do niego było konieczne dla zachowania logiki i spójności wywodu. Analizie poddane zostały trzy stany prawne: obowiązujący do dnia 30 czerwca 2015 r., obowiązujący od dnia 1 lipca 2015 r. do dnia 14 kwietnia 2016 r. oraz obowiązujący od dnia 15 kwietnia 2016 r.

Punktem wyjścia dla omawianej problematyki jest art. 77 ust. 1 Konstytucji ${ }^{5}$, który stanowi: „Każdy ma prawo do wynagrodzenia szkody, jaka została mu wyrządzona przez niezgodne z prawem działanie organu władzy publicznej”.

Za M. Haczkowską ${ }^{6}$ należy podkreślić, że konstytucjonalizacja prawa do odszkodowania regulowanego w art. 77 ust. 1 Konstytucji, stanowi ważny krok w zakresie ochrony praw jednostek wobec arbitralnych działań władzy.

W tym miejscu należy przytoczyć niezwykle istotny w kontekście poruszanej tematyki fragment wyroku Trybunału Konstytucyjnego ${ }^{7}$, odnoszący się do treści oraz stosowania art. 77 ust. 1 Konstytucji. We wskazanym wyroku TK stwierdził:

W przepisie tym wyraża się myśl ogólną, iż bezprawne wyrządzenie szkody przez władzę publiczną daje prawo do odszkodowania. Jest to prawo konstytucyjne. Ta konstatacja jest decydująca dla normatywnego znaczenia art. 77 ust. 1 Konstytucji. Przepis ten jednak sam przez się nie wskazuje wyczerpująco ani jaka szkoda (w jakich granicach) ma podlegać naprawieniu, ani nie rozstrzyga co decyduje o wymaganej przesłance bezprawności, nie wspominając już o drodze, na jakiej realizacja uprawnienia odszkodowawczego ma nastąpić. Te kwestie mogą być zatem - co do zasady - regulowane w ustawach zwykłych. Niepodobna więc jednak w art. 77 ust. 1 Konstytucji upatrywać generalnej, wyczerpującej i przede wszystkim wystarczającej podstawy do żądania pełnego odszkodowania, za każde zdarzenie powodujące szkodę, pozostającą nawet w odległym związku kauzalnym, za każdy rodzaj nieprawidłowości w zachowaniu władzy publicznej. Gdyby tak było, stawałaby się zbędna dalsza regulacja tych kwestii w ustawodawstwie zwykłym co do zakresów pominiętych w samym normowaniu art. 77 ust. 1 Konstytucji.

W tym kontekście oczywiste jest, że art. 77 ust. 1 Konstytucji nie może stanowić samoistnej przesłanki dochodzenia odszkodowania. Konieczne jest zatem powołanie się na konkretny przepis aktu rangi ustawowej.

5 Konstytucja RP z dnia 2 kwietnia 1997 r. (Dz.U. nr 78 poz. 486).

6 M. Haczkowska, Srodki ochrony wolności i praw, [w:] Komentarz. Konstytucja Rzeczypospolitej Polskiej, red. M. Haczkowska, Warszawa 2014, s. 162.

7 Wyrok TK z dnia 20 stycznia 2004 r., SK 26/03, OTK-A 2004, nr 1, poz. 3 (podaję za: P. Wiliński, Proces karny w świetle Konstytucji, Warszawa 2011, s. 265). Cf. L. Garlicki, Komentarz do art. 77 Konstytucji, [w:] Konstytucja Rzeczypospolitej Polskiej. Komentarz, red. L. Garlicki, t. 5, Warszawa 2007, s. 8-11. 
Jedną z istotniejszych instytucji procedury karnej, która realizuje gwarancje $\mathrm{z}$ art. 77 ust. 1 Konstytucji jest odszkodowanie i zadośćuczynienie uregulowane w rozdziale 58 k.p.k. ${ }^{8}$ L. Garlicki ${ }^{9}$ zwrócił uwagę, że gwarancje z art. 77 ust. 1 Konstytucji mają swoje przełożenie także na sytuację prawną uczestników postępowania karnego, mimo że wskazany przepis w pierwszej kolejności odnosi się do regulacji prawa cywilnego. Jak słusznie wskazał Ł. Chojniak ${ }^{10}$, norma wyrażona w art. 77 ust. 1 Konstytucji została doprecyzowana w przepisie art. 41 ust. 5 Konstytucji, który stanowi, że „każdy bezprawnie pozbawiony wolności ma prawo do odszkodowania"11. Zasadne jest więc stwierdzenie, że ustawodawca wskazał wprost w przytoczonych zapisach Konstytucji, iż procedura odszkodowawcza z tytułu niesłusznego skazania oraz niesłusznego stosowania środków przymusu powinna być uregulowana odrębnie od zasad ogólnych prawa cywilnego. Taką regulacją jest właśnie rozdział 58 k.p.k. Przy czym, jak przyjęto w doktrynie ${ }^{12}$, Konstytucja posługuje się terminem „szkoda” w szerokim znaczeniu, czyli nie ogranicza się do pojęcia szkody materialnej ${ }^{13}$. Mowa tu zatem o każdym uszczerbku w prawnie chronionych dobrach danego podmiotu, zarówno tych o charakterze majątkowym, jak i niemajątkowym. W konsekwencji możliwa jest także odpowiedzialność władzy z tytułu naruszenia dóbr osobistych jednostki, m.in. w zakresie zadośćuczynienia pieniężnego za doznaną krzywdę niemajątkową.

Za P. Wilińskim ${ }^{14}$ warto podkreślić, że zasada odpowiedzialności odszkodowawczej, wyrażona w art. 41 ust. 5 Konstytucji, została oparta na konstrukcji bezprawności. Przepis ten wymaga bowiem dla powstania podstawy do odpowiedzialności zaistnienia bezprawnego, nie zaś niesłusznego, pozbawienia wolności. Bezprawność oznacza tu „oczywisty brak podstawy prawnej albo instrumentalne stosowanie obowiązujących przepisów z obejściem ich istoty, lecz dla uzyskania celów z tymi przepisami niespójnych (nadużycie prawa)".

Nie ulega wątpliwości, że zaistnienie pomyłki w działalności organów wymiaru sprawiedliwości czy też organów ścigania jest nieuniknione. Fakt ten stanowi niejako podsta-

8 Cf. P. Cioch, Odpowiedzialność Skarbu Państwa z tytutu niestusznego skazania, Warszawa 2007, s. 53-62.

9 L. Garlicki, op. cit., s. 5-8.

10 K.T. Boratyńska, Ł. Chojniak, W. Jasiński, Postępowanie karne, Warszawa 2015, s. 650-651.

11 Tak też B. Banaszak, Konstytucja Rzeczypospolitej Polskiej. Komentarz, Warszawa 2012, s. 272. Autor wskazuje, że art. 41 ust. 5 stanowi lex specialis wobec art. 77 Konstytucji i jest dodatkową, istotną gwarancją chroniącą przed nadużyciami instytucji pozbawienia i ograniczenia wolności.

12 W. Skrzydło, Konstytucja Rzeczypospolitej Polskiej. Komentarz, Warszawa 2013, s. 92; M. Haczkowska, op. cit., s. 163; B. Banaszak, op. cit., s. 451-462; P. Wiliński, op. cit., s. 201.

13 Wyrok TK z dnia 4 grudnia 2001 r., SK 18/00, OTK 2001, nr 8, poz. 256. Według TK „użyte w Konstytucji pojęcie szkody powinno być rozumiane w sposób przyjęty na gruncie prawa cywilnego [...]. Chodzi tu o każdy uszczerbek w prawnie chronionych dobrach danego podmiotu, zarówno o charakterze majątkowym, jak i niemajątkowym”.

14 P. Wiliński, op. cit., s. 201. 
wę konieczności regulowania przez ustawodawcę szczegółowych przesłanek bądź wzruszania prawomocnych orzeczeń (kasacja, wznowienie postępowania), bądź też ponoszenia przez państwo odpowiedzialności za szkody wynikające z niesłusznego zastosowania szczególnie dolegliwych dla danej jednostki środków. Wyrządzenie szkody lub krzywdy w konsekwencji wadliwego zastosowania przepisów prawa stanowi bezsprzecznie ingerencję w sferę wykonywania praw jednostki. Nie można jednak przerzucić ponoszenia konsekwencji tej ingerencji na pokrzywdzoną jednostkę. Odpowiedzialność powinno ponieść państwo, a właściwie jego organy ${ }^{15}$.

Przechodząc do szczegółowej analizy tematyki opracowania, w pierwszej kolejności należy wskazać, że już na początku lat 90 . P. Hofmański ${ }^{16}$ podnosił problem pomijania w doktrynie procesu karnego problematyki odpowiedzialności Skarbu Państwa za szkody wyrządzone zastosowaniem, innych niż tymczasowe aresztowanie, środków przymusu, w sytuacji gdy publikowane są obszerne opracowania dotyczące odszkodowania za szkody spowodowane oczywiście niesłusznym tymczasowym aresztowaniem ${ }^{17}$. Zagadnienie odpowiedzialności państwa za szkody wyrządzone przez funkcjonariuszy państwowych było $\mathrm{z}$ kolei szeroko analizowane w doktrynie prawa cywilnego ${ }^{18}$. Przy czym z uwagi na kształt systemu prawnego rozważania cywilistów dotyczyły także szkody wyrządzonej środkami przymusu w postępowaniu karnym. P. Hofmański słusznie skrytykował taki stan rzeczy, wskazując na specyfikę procesu karnego, a w związku z tym konieczność analizy problemu w doktrynie karnistycznej. Ponadto wysunął postulat uregulowania przedmiotowej instytucji w k.p.k. Przedstawił w tym względzie następujące argumenty ${ }^{19}$ :

15 P. Hofmański, E. Sadzik, K. Zgryzek, Kodeks postępowania karnego, t. III, Komentarz do artykutów 468-682, Warszawa 2012, s. 464.

16 P. Hofmański, Problem odpowiedzialności państwa za szkody spowodowane środkami przymusu w procesie karnym, [w:] Stosowanie środków przymusu w procesie karnym. Problem karnoprocesowych ograniczeń praw obywatelskich, red. K. Amelung, K. Marszał, Katowice 1990, s. 168-169. Cf. idem, Nowe oblicze środków przymusu w procesie karnym, „Białostockie Studia Prawnicze” 1992, nr 1, s. 190 i n., gdzie autor nawiązuje do problematyki konieczności uregulowania na gruncie k.p.k. odpowiedzialności Skarbu Państwa za niesłuszne zastosowanie środków przymusu.

$17 \mathrm{~W}$ okresie publikacji wskazanego wyżej opracowania P. Hofmańskiego odpowiedzialność państwa za szkody spowodowane niesłusznym zatrzymaniem była dopiero co wprowadzoną instytucją (na mocy ustawy z dnia 29 maja 1989 r. o zmianie niektórych przepisów prawa karnego, prawa o wykroczeniach oraz innych ustaw, Dz.U. nr 34 poz. 180), dlatego też we wskazanym okresie nie dokonano jeszcze jej analizy naukowej w piśmiennictwie.

18 P. Hofmański przywołał tu m.in. opracowania monograficzne J. Kosika, Zasady odpowiedzialności państwa za szkody wyrządzone przez funkcjonariuszów, Wrocław 1961; A. Szpunara, Odpowiedzialność Skarbu Państwa za funkcjonariuszy, Warszawa 1985.

19 P. Hofmański, op. cit., s. 169-186. Autor szeroko opisał argumentację na rzecz konieczności uregulowania kwestii odpowiedzialności państwa za szkody wyrządzone na skutek zastosowania przymusu procesowego. Przyznał jednak, że wiele jego twierdzeń w publikacji można uznać za kontrowersyjne. W niniejszym opracowaniu przedmiotowy wywód przedstawiono w wersji skróconej do potrzebnego minimum. 
- regulacja odpowiedzialności państwa za szkody wyrządzone zastosowaniem, innych niż tymczasowe aresztowanie, środków przymusu w k.p.k., przeniesie właściwość z sądów cywilnych (właściwych na zasadach ogólnych) na sądy karne, które $\mathrm{z}$ uwagi na swą specyfikę są $\mathrm{w}$ stanie lepiej zbadać kontekst sprawy i jej stan faktyczny,

- konieczność unifikacji regulacji prawnej odpowiedzialności państwa za szkody wyrządzone na skutek zastosowania przymusu procesowego, poprzez pełną regulację w k.p.k.,

- w procesie demokratyzacji procesu karnego niedopuszczalne jest utrzymywanie regulacji, które w sposób oczywisty nie gwarantują osobom niesłusznie dotkniętym negatywnymi skutkami działań organów ścigania i wymiaru sprawiedliwości uzyskania stosownego odszkodowania i zadośćuczynienia,

- aby regulacja odpowiedzialności państwa za szkody wyrządzone zastosowaniem, innych niż tymczasowe aresztowanie, środków przymusu w k.p.k. miała sens, konieczne jest właściwe ukształtowanie podstaw prawnych stosowania przymusu.

Jednym z czołowych przedstawicieli doktryny, który silnie forsował regulację odpowiedzialności odszkodowawczej państwa za niesłuszne oskarżenie oraz niesłuszne stosowanie w toku procesu karnego innych środków przymusu niż zatrzymanie czy tymczasowe aresztowanie, jest Ł. Chojniak. Autor wyrażał krytyczne zdanie na temat stanu prawnego sprzed 1 lipca $2015 \mathrm{r}$. Wskazywał, że nie można uznać za prawidłowy poglądu, zgodnie z którym prowadzenie postępowania karnego przeciwko niewinnemu może wyrządzić mu szkodę lub krzywdę tylko wtedy, gdy dojdzie do jego zatrzymania, tymczasowego aresztowania czy też, wreszcie, skazania ${ }^{20}$.. Chojniak $^{21}$ przedstawiał zarzut braku zupełności omawianej regulacji. Za pożądane wskazywał uzupełnienie jej o regulację odpowiedzialności państwa za niesłuszne oskarżenie, z zastrzeżeniem, że prawo do odszkodowania powinno przysługiwać także osobie niesłusznie oskarżonej przez prokuratora, czyli o czyn ścigany z oskarżenia publicznego. Przepis taki stanowiłby, zdaniem Ł. Chojniaka, zarówno gwarancję rekompensaty poniesionej szkody i doznanej krzywdy na skutek fałszywych oskarżeń, jak również mógłby ograniczyć liczbę wadliwych, nietrafnie uzasadnionych aktów oskarżenia, które niesłusznie oskarżają osoby, którym nie można dowieść winy. Ponadto Ł. Chojniak ${ }^{22}$ wskazywał na konieczność regulacji odpowiedzialności państwa za niesłuszne zastosowanie innych, niż zatrzymanie czy tymczasowe aresztowanie, środków przymusu. Zdaniem autora zastosowanie wobec po-

20 Ł. Chojniak, Odszkodowanie za niestuszne skazanie, tymczasowe aresztowanie lub zatrzymanie, Warszawa 2013, s. XXX (wstęp).

21 Ł. Chojniak, Odszkodowanie za niestuszne skazanie w polskim procesie karnym - wybrane zagadnienia, [w:] Węztowe problemy procesu karnego, red. P. Hofmański, Warszawa 2010, s. 488-489.

22 Ibidem, s. 293-295. 
dejrzanego czy oskarżonego takich instytucji, jak: poręczenie majątkowe, społeczne lub osoby godnej zaufania, dozór Policji, nakaz opuszczenia lokalu mieszkalnego, zawieszenie w czynnościach służbowych, zakaz opuszczania kraju czy wreszcie zabezpieczenie majątkowe, właściwie zawsze może wyrządzić danej osobie - bądź wymierną szkodę majątkową, bądź krzywdę (cierpienia fizyczne i psychiczne). Ł. Chojniak ${ }^{23}$ w odniesieniu do stosowania zabezpieczenia majątkowego podkreślił, że choć zabezpieczenie nie pozbawia władztwa oskarżonego nad jego własnością, to jego orzeczenie może negatywnie wpływać na sytuację majątkową danej osoby. Dla przykładu autor wymienił obciążenie nieruchomości oskarżonego hipoteką przymusową, co powoduje utratę jej wartości ekonomicznej z uwagi na wpis hipoteki do księgi wieczystej.

Na szczególną uwagę zasługuje również stanowisko wyrażone przez R.A. Stefańskiego $^{24}$, który podnosił, że rozszerzenie odpowiedzialności Skarbu Państwa „zwiększyłoby odpowiedzialność sędziów i prokuratorów za podejmowane decyzje oraz [...] wpłynęłoby na świadomość społeczeństwa, że organy procesowe muszą ponieść konsekwencje swoich decyzji procesowych”. Autor podkreślał ponadto, że zastosowanie innych środków przymusu niż tymczasowe aresztowanie czy zatrzymanie również może wyrządzić szkodę lub krzywdę, dlatego konieczne jest rozszerzenie omawianej regulacji ${ }^{25}$.

Przechodząc do analizy dogmatycznej omawianej problematyki na gruncie przepisów k.p.k., należy wskazać, że w stanie prawnym obowiązującym do dnia 30 czerwca 2015 r. ${ }^{26}$ przepis art. 552 k.p.k. określał następujące prawnomaterialne podstawy roszczeń o odszkodowanie lub zadośćuczynienie: niesłuszne skazanie, w wyniku którego wykonana została kara w całości lub w części (art. 552 § 1 i 2), niesłuszne orzeczenie i wykonanie środka zabezpieczającego (art. 552 § 3 ), niewątpliwie niesłuszne tymczasowe aresztowanie, także w związku z wykonywaniem Europejskiego Nakazu Aresztowania (art. 552 $\S 4$ ) oraz niewątpliwie niesłuszne zatrzymanie (art. 552 § 4) ${ }^{27}$.

23 Ibidem, s. 295.

24 R.A. Stefański, Odporwiedzialnośc za niestuszne skazanie, nierwątpliwie niestuszne oskarżenie, przedstawienie zarzutów lub zastosowanie nieizolacyjnego środka zapobiegawczego, „Prokuratura i Prawo" 2012, nr 12, s. 31-49. Przedmiotowe stanowisko spotkało się z krytyczną, nie do końca jednak słuszną, odpowiedzią B. Mik, O potrzebie dodatkowego, szczególnego unormowania odpowiedzialności odszkodowawczej Skarbu Panstwa za niestuszne skazanie oraz niewatpliwie niestuszne oskarżenie, przedstawienie zarzutów lub zastosowanie nieizolacyjnego środka zapobiegawczego, „Prokuratura i Prawo” 2012, nr 12, s. 50-71.

25 R.A.Stefański, op. cit., s. 47; także A.M.Tęcza-Paciorek, O potrzebie uregulowania odszkodowania za niestuszne oskarżenie, „Przegląd Sądowy” 2011, nr 2, s. 69-79; eadem, Zasada domniemania niewinności w polskim procesie karnym, Warszawa 2012, s. 310-319.

26 Mowa tu o treści przepisu obowiązującej w okresie od 1 lipca 2003 r. do 30 czerwca 2015 r.

27 L.K. Paprzycki, Komentarz do rozdziatu 58 k.p.k., [w:] Kodeks postępowania karnego, t. II, Komentarz do art. 425-673, red. L.K. Paprzycki, Warszawa 2013, s. 421. 
Jedynie na marginesie trzeba zaznaczyć, że art. 552 k.p.k. w wersji pierwotnej (obowiązującej od 1 stycznia 1998 r. do 30 czerwca 2003 r. $^{28}$ ) stanowił odpowiednik art. 487 k.p.k. z 1969 r. W porównaniu z nim szerzej określał podstawy roszczeń odszkodowawczych osób niesłusznie skazanych. Wynikało to z wprowadzenia instytucji nieważności orzeczeń. Odszkodowanie i zadośćuczynienie mogła uzyskać także osoba, która została uniewinniona lub skazana na łagodniejszą karę w wyniku stwierdzenia nieważności orzeczenia. Zmiany w treści omawianego przepisu wyniknęly ze zniesienia instytucji nieważności.

W tym kontekście należy wskazać, że do dnia 30 czerwca 2015 r. k.p.k. nie regulował kwestii odpowiedzialności Skarbu Państwa za niesłuszne stosowanie środków przymusu.

Do momentu wejścia w życie kolejnej nowelizacji, tj. do dnia 1 lipca 2015 r., w doktrynie procesu karnego pojawiły się liczne postulaty dotyczące konieczności uregulowania kwestii odpowiedzialności państwa za niesłuszne oskarżenie oraz właśnie za niesłuszne stosowanie środków przymusu ${ }^{29}$.

Ostatecznie ustawodawca zdecydował się przyjąc jedną z bardziej fundamentalnych oraz innowacyjnych zmian, jakie wprowadzono wspomnianą już wcześniej „wielką” nowelizacją k.p.k. ${ }^{30}$ Regulacje z rozdziału 58 k.p.k. zostały w istotny sposób zmienione i rozbudowane. Wprowadzono nowy tytuł rozdziału, przyjmując iż dotyczy: „Odszkodowania i zadośćuczynienia za niesłuszne skazanie oraz niesłuszne stosowanie środków przymusu procesowego". Przepis art. 552 § 1 k.p.k. odnosił się, tak jak wcześniej, do niesłusznego skazania, przy czym przyznano możliwość uzyskania odszkodowania i zadośćuczynienia także za niesłuszne zastosowanie środków karnych, których dolegliwość faktycznie często przekraczała dolegliwość samej kary. Odszkodowanie można było uzyskać również za niezasadne wykonywanie wobec oskarżonego, ostatecznie uniewinnionego, środka przymusu określonego w dziale VI k.p.k., czyli zatrzymania, środków zapobiegawczych oraz zabezpieczenia majątkowego. W razie ponownego skazania oskarżonego odszkodowanie i zadośćuczynienie przysługiwały także za niezasadne wykonywanie środków przymusu w zakresie, w jakim nie zostały zaliczone na poczet orzeczonych kar i środków. W ramach opisywanej nowelizacji do k.p.k. dodano art.552a

28 Wersja pierwotna przepisu została zmieniona ustawą z dnia 10 stycznia 2003 r. o zmianie ustawy - Kodeks postępowania karnego, ustawy - Przepisy wprowadzające Kodeks postępowania karnego, ustawy o świadku koronnym oraz ustawy o ochronie informacji niejawnych (Dz.U. nr 17 poz. 155), która weszła w życie 1 lipca 2003 r.

29 Cf. literatura wskazana wcześniej, przy okazji prezentowania stanowiska doktryny w zakresie omawianej materii.

30 Rozdział 58 k.p.k. został zmieniony i rozbudowany ustawą z dnia 27 września 2013 r. (Dz.U. poz. 1247), która weszła w życie 1 lipca 2015 r. Cf. K. Dąbkiewicz, op. cit., s. 556-557. Natomiast przepisy rozdziału 58 k.p.k. nie były przedmiotem dalszych modyfikacji, wynikających z ustawy z dnia 20 lutego 2015 r. o zmianie ustawy Kodeks karny oraz niektórych innych ustaw (Dz.U. poz. 396). 
i art. 552b. Analiza drugiego z nich, jako dotyczącego jedynie roszczenia o odszkodowanie i zadośćuczynienie za niewątpliwie niesłuszne zatrzymanie w związku z prowadzonym postępowaniem karnym, pozostaje poza ramami niniejszego opracowania. Istotna będzie z kolei analiza pierwszego z nich, który stanowił rozszerzenie zakresu przedmiotowego rozdziału 58 k.p.k. Wprowadził do postępowania karnego nową regulację przyznającą prawo do odszkodowania i zadośćuczynienia w wypadku, gdy do uniewinnienia lub umorzenia postępowania in personam doszło w drodze prawomocnego wyroku, bez wzruszania orzeczenia w trybie nadzwyczajnych środków zaskarżenia, także gdy umorzenie postępowania nastąpiło na etapie postępowania przygotowawczego. Regulacja ta stanowiła wypełnienie wskazywanych wyżej postulatów doktryny dotyczących odszkodowania za tzw. niesłuszne oskarżenie ${ }^{31}$. Wprowadzona w art. 552a $§ 1$ odpowiedzialność Skarbu Państwa została jednak ograniczona do sytuacji, gdy wobec osoby uniewinnionej, lub wobec której umorzono postępowanie, wykonane zostały w tym postępowaniu środki przymusu. W omawianym przepisie przyjęto założenie, że z uwagi na treść wydanego orzeczenia wykonanie środka przymusu było niesłuszne. Miało to miejsce w sytuacji, gdy w toku postępowania karnego zastosowano środek przymusu i był on wykonany, a następnie oskarżony został uniewinniony w pierwszej lub drugiej instancji albo postępowanie zostało umorzone, zarówno na etapie postępowania sądowego, jak i przygotowawczego ${ }^{32}$.

Z kolei przepisem art. 552a § 2 k.p.k. wprowadzono możliwość dochodzenia przez osoby skazane, a także przez osoby, wobec których warunkowo umorzono postępowanie (art. 552a § 3 k.p.k.), odszkodowania lub zadośćuczynienia, gdy zastosowane środki zapobiegawcze lub zabezpieczenie majątkowe przewyższyły zastosowaną reakcję $\mathrm{karną}^{33}$. Przedmiotowa regulacja nie obejmowała natomiast swym zakresem prawa do odszkodowania i zadośćuczynienia w wypadku zastosowania środków przymusu niepodlegających zaliczeniu na poczet orzeczonej kary lub środków karnych (np. dozór Policji, zakaz opuszczania kraju), nawet gdyby ustalono, że zastosowanie takiego środka wobec osoby skazanej było niezasadne ${ }^{34}$.

Istotna była również zmiana wprowadzona w art. $553 \S 2$ k.p.k. Przepis ten wprowadził, nieistniejące dotąd w kodeksie, wyłączenie roszczenia o odszkodowanie lub zadośćuczynienie z tytułu wykonywania środka przymusu, co zachodzi w sytuacji, gdy jego zastosowanie nastąpiło $\mathrm{z}$ powodu bezprawnego utrudniania postępowania przez oskarżonego. Przy czym sformułowanie „bezprawne utrudnianie” należy interpretować ściśle jako konkretne działania powodujące zakłócenie prawidłowego toku postępowa-

31 Ibidem, s. 558-559.

32 D. Świecki, Komentarz do rozdziatu 58 k.p.k., [w:] Kodeks postępowania karnego. Komentarz, red.

D. Świecki, t. II, Warszawa 2015, s. 594.

33 K. Dąbkiewicz, op. cit., s. 560.

34 D. Świecki, op. cit., s. 595. 
nia karnego. Jeżeli podstawą zastosowania środka przymusu była jedynie obawa takiego utrudniania, nie było to podstawą do zastosowania omawianego wyłączenia $\mathrm{z}$ art. 553 $\S 2$ k.p.k. ${ }^{35}$

Zanim nastąpi szczegółowe omówienie treści wskazanych wyżej przepisów, należy przytoczyć argumentację, jaka przyświecała ustawodawcy ${ }^{36}$ w kontekście wprowadzenia ich do obowiązującego porządku prawnego. Przede wszystkim wskazano, że dotychczasowa regulacja wymagała uzupełnienia, gdyż odsyłanie osób w zakresie nieuregulowanym w rozdziale 58 k.p.k. ,na drogę, jak wiadomo w praktyce długotrwałego, postępowania cywilnego nie jest zasadne, jeśli uwzględni się, że szkoda i krzywda spowodowana została w specyficznych warunkach, bo w postępowaniu karnym, przez państwowe organy ścigania i wymiar sprawiedliwości w sprawach karnych. Jak najbardziej zasadne jawi się więc kompensowanie tych szkód i krzywd w trybie karno-procesowym, z odpowiednim tylko stosowaniem przepisów prawa cywilnego, w tym procesowego" ${ }^{37}$. W odniesieniu do treści art.552a k.p.k. w uzasadnieniu wskazano, że „w praktyce bywa, że stosowane środki zapobiegawcze i zabezpieczenie majątkowe przewyższają niekiedy rozmiar orzeczonych kar i środków karnych, na poczet których można było je zaliczyć, albo kary te i środki są dostosowywane do rozmiarów i czasokresów wskazanych środków przymusu. Wydaje się zatem niezbędne wprowadzenie możliwości dochodzenia przez osoby skazane oraz wobec których postępowanie warunkowo umorzono, stosownych roszczeń, także wówczas, gdy środki przymusu procesowego przewyższają zastosowaną reakcję karną"38. Wreszcie w odniesieniu do wprowadzonej nowelizacją treści art. 553 § 2 k.p.k. uznano, że poszerzenie zakresu odpowiedzialności odszkodowawczej Skarbu Państwa nie może oznaczać, iż odszkodowanie takie będzie służyło osobie uniewinnionej lub wobec której umorzono bądź warunkowo umorzono postępowanie, gdy stosowane wobec niej uprzednio środki zapobiegawcze spowodowane były podejmowaniem przez nią w toku postępowania działań bezprawnie utrudniających to postępowanie. Oskarżony korzystając z prawa do obrony nie może bowiem podejmować tego rodzaju działań, a jego obrona powinna mieścić się w granicach prawa.

Warunkiem możliwości dochodzenia, na podstawie art. 552 § 1 k.p.k., roszczeń o odszkodowanie lub zadośćuczynienie za niezasadne wykonanie środka przymusu było niezaliczenie okresu stosowania środków przymusu na poczet orzekanych środków reakcji prawnokarnej. Taka sytuacja miała miejsce albo ze względu na ich nieorzeczenie (wyrok uniewinniający oraz umarzający postępowanie), albo ze względu na niemożność ich

35 K. Dąbkiewicz, op. cit., s. 562.

36 Uzasadnienie Komisji Kodyfikacyjnej Prawa Karnego projektu ustawy o zmianie ustawy Kodeks postępowania karnego i niektórych innych ustaw, https://bip.ms.gov.pl/pl/projekty-aktow-prawnych/prawo-karne/ [dostęp: 1.04.2016].

37 Ibidem, s. 95.

38 Ibidem, s. 98. 
zaliczenia (w części lub w całości) na poczet środków orzeczonych w wyroku w danej sprawie $^{39}$. Reguła ta obowiązywała również na gruncie art. 552a § 1 k.p.k., gdyż uniewinnienie oskarżonego lub umorzenie wobec niego postępowania w wypadkach innych niż określone w art. $552 \S \S 1-3$ oznaczało, że okresy stosowania środków przymusu nie mogły zostać zaliczone. Zgodnie ze stanowiskiem Sądu Apelacyjnego w Katowicach ${ }^{40}$ treść art. 552a § 1 k.p.k. wskazywała, że w zasadzie jedyną przesłanką warunkującą odpowiedzialność odszkodowawczą Skarbu Państwa za zatrzymanie (ale też za inne środki przymusu) było istnienie prawomocnego wyroku uniewinniającego oskarżonego lub umarzającego postępowanie. Była to odpowiedzialność niejako automatyczna, gdyż ustawodawca nie przewidział żadnych okoliczności, które w przypadku wydania wskazanego rozstrzygnięcia odpowiedzialność tę by ograniczały lub wyłączały. Bez znaczenia pozostawało natomiast to, czy środki przymusu były stosowane zgodnie $z$ właściwymi przepisami określonymi w Kodeksie postępowania karnego. Jedyną istotną przesłanką dla oceny słuszności dochodzonego roszczenia było rozstrzygnięcie w sprawie karnej prowadzonej przeciwko wnioskodawcy, które nie zostało jeszcze wydane.

$Z$ kolei zgodnie $z$ art. 552a $§ 2$ k.p.k. w przypadku skazania oskarżonego roszczenie przysługiwało tylko w odniesieniu do środków zapobiegawczych lub zabezpieczenia majątkowego w zakresie, w jakim z uwagi na rodzaj i rozmiar orzeczonych kar lub środków karnych nie można było zaliczyć na ich poczet okresów wykonywania odpowiednich środków zapobiegawczych podlegających takiemu zaliczeniu lub w pełni wykorzystać zastosowanego zabezpieczenia majątkowego ${ }^{41}$.

Odnosząc te uwagi do instytucji zabezpieczenia majątkowego, stanowiącego szczególny środek przymusu, należy wskazać, że wprowadzone ustawą z 2013 r. rozszerzenie zakresu odpowiedzialności Skarbu Państwa za niesłuszne stosowanie środków przymusu, w tym zabezpieczenia majątkowego co do zasady należy ocenić pozytywnie. Jednakże regulacja ta, w odniesieniu do zabezpieczenia majątkowego, zawierała kilka elementów, które powinny były zostać zmodyfikowane.

W pierwszej kolejności należy wskazać, że celem zabezpieczenia majątkowego jest zabezpieczenie na mieniu oskarżonego wykonania przyszłego orzeczenia ${ }^{42}$, a mianowicie kar i środków karnych o charakterze majątkowym, które mogą zostać orzeczone

39 W. Jasiński, Komentarz do rozdziatu 58 k.p.k., [w:] Kodeks postępowania karnego. Komentarz, red. J. Skorupka, Warszawa 2015, s. 1301.

40 Wyrok SA w Katowicach z dnia 3 lipca 2015 r., II Aka 220/15, „Prokuratura i Prawo” 2016, nr 3, poz. 36.

41 Cf. uwagi krytyczne W. Jasińskiego, Odszkodowanie i zadoścuczynienie za niestuszne skazanie, wykonanie środka zabezpieczającego oraz niezasadne stosowanie środków przymusu po nowelizacji kodeksu postepowania karnego, „Prokuratura i Prawo” 2015, nr 9, s. 63-68. Cf. P. Czarnecki, Odpowiedzialnośc Skarbu Państwa za btędy wymiaru sprawiedliwości w sprawach karnych po 1 lipca 2015 r., „Internetowy Przegląd Prawniczy TBSP UJ”2015, nr 2, s. 52-76.

42 J. Grajewski, Przebieg procesu karnego, Warszawa 2004, s. 126. 
w wyroku sądowym, przepadku i środków kompensacyjnych zasądzonych w postępowaniu karnym, a także kosztów sądowych. Charakter tej instytucji jest zatem odmienny od innych środków przymusu, a w szczególności środków zapobiegawczych, które mają zabezpieczać tok toczącego się postępowania, tak by w procesie nie wystąpiły żadne trudności w jego przeprowadzeniu. Zabezpieczenie majątkowe zabezpiecza zaś wykonalność zapadłego w przyszłości orzeczenia. W konsekwencji powoduje to trudności w uregulowaniu jednolitych przepisów dotyczących odpowiedzialności Skarbu Państwa w tym zakresie. Jak zostało wyżej podkreślone, bardzo ważną zmianą ustawy nowelizującej z 2013 r. było wyraźne uzależnienie tej odpowiedzialności od tego, czy środki przymusu zostały zaliczone na poczet orzeczonych środków reakcji prawnokarnej. Tymczasem trudno mówić w kontekście zabezpieczenia majątkowego o tego typu zaliczeniu. Zabezpieczone mienie jest bowiem wykorzystywane dopiero w sytuacji, gdy oskarżony przykładowo nie zapłaci w terminie orzeczonej grzywny. W takiej sytuacji egzekucja następuje właśnie z zabezpieczonego wcześniej mienia. Dlatego też treść art. 552 § 1 k.p.k. nie była sformułowana precyzyjnie, co w praktyce mogło budzić uzasadnione wątpliwości co do jego stosowania w odniesieniu do zabezpieczenia majątkowego. W tym kontekście należy wskazać, że ustawodawca wykazał się niekonsekwencją, gdyż w art. 552a $\S 2$ k.p.k. wskazał na „wykorzystanie” zastosowanego zabezpieczenia majątkowego, co należy uznać za stwierdzenie poprawne. Zdziwienie budzi więc fakt niedokonania takiego rozróżnienia w art. 552 § 1 k.p.k.

Należy również wskazać na kolejny problem w kontekście odszkodowania lub zadośćuczynienia za niesłuszne zastosowanie zabezpieczenia majątkowego. Mianowicie możliwe jest powstanie szkody zarówno majątkowej, jak i niemajątkowej, także w sytuacji gdy zastosowane zabezpieczenie majątkowe zostało po jakimś czasie uchylone w całości lub w części, gdyż ustały przyczyny, dla których zostało ono zastosowane w określonym rozmiarze, lub powstały przyczyny uzasadniające jego uchylenie choćby w części (art. 291 $\S 4$ k.p.k.). Przykładowo właściciel, z uwagi na obciążenie nieruchomości w ramach zastosowanego zabezpieczenia majątkowego hipoteką przymusową, stracił trzech kupców, którzy byli zainteresowani kupnem przedmiotowej nieruchomości jedynie w stanie nieobciążonym. Przyjmijmy, że zabezpieczenie zostało uchylone w stosunku do podejrzanego jeszcze na etapie postępowania przygotowawczego. Następnie jednak osoba ta została skazana prawomocnym wyrokiem, przy czym wniesiona kasacja została oddalona. Zastosowania nie znajdzie tu na pewno art.552a k.p.k., gdyż odnosi się do sytuacji uniewinnienia lub umorzenia postępowania. W przedstawionej sytuacji oczywiste jest, że na gruncie art. 552 § 1 k.p.k. w brzmieniu obowiązującym do dnia 14 kwietnia 2016 r. odszkodowanie ani zadośćuczynienie nie przysługiwały. Jednak z uwagi na specyfikę zabezpieczenia majątkowego, jego niesłuszne zastosowanie i powstanie w związku z tym szkody były kwestią całkowicie niezależną od skazania, które nastąpiło w przedmiotowym przypadku. Powinny więc być traktowane oddzielnie i bez powiązania. Organ błęd- 
nie ocenił bowiem wystąpienie przesłanek z art. 291 § 1 k.p.k., tak że zaszła uzasadniona obawa, iż bez takiego zabezpieczenia wykonanie orzeczenia będzie niemożliwe albo znacznie utrudnione. Dlatego należałoby postulować, aby w takiej sytuacji możliwe było dochodzenie odpowiedzialności Skarbu Państwa. Moim zdaniem kwestia orzekania odszkodowania i zadośćuczynienia za niesłuszne zastosowanie zabezpieczenia majątkowego jest szersza niż w zakresie innych środków przymusu. Wynika to przede wszystkim ze specyfiki przedmiotowej instytucji i wymagałoby dogłębnej analizy.

Możliwym rozwiązaniem powyższego problemu byłoby wprowadzenie sposobności wystąpienia o odszkodowanie czy zadośćuczynienie w sytuacji, gdy postępowanie nie zostało jeszcze zakończone ${ }^{43}$. Przyjmijmy, że w przytoczonym wyżej przykładzie proces karny toczył się kilka lat. Brak możliwości sprzedaży nieruchomości przez oskarżonego, spowodowany zastosowanym, a następnie uchylonym zabezpieczeniem, doprowadził oskarżonego wraz z rodziną do ruiny finansowej. Ponadto nieruchomość z roku na rok coraz bardziej niszczała, a z uwagi na tę sytuację oskarżony mocno podupadł na zdrowiu, również psychicznym. Takiej sytuacji można by zapobiec poprzez wprowadzenie regulacji dopuszczającej możliwość ubiegania się o pociągnięcie Skarbu Państwa do odpowiedzialności jeszcze przed prawomocnym zakończeniem postępowania karnego. Zastosowanie zabezpieczenia majątkowego, a następnie jego uchylenie nie miało w tej sytuacji związku z zapadłym wyrokiem, w żaden sposób na niego nie wpłynęło. W kontekście całego postępowania karnego była to kwestia wypadkowa. Dlatego też zasadne byłoby umożliwienie oskarżonemu wcześniejszego rozliczenia państwa za niezasadne obciążenie własności, które spowodowało bezpośrednią szkodę majątkową i niemajątkową.

Rozważając tę sytuację z innego punktu widzenia, kiedy oskarżony zostałby w ostateczności uniewinniony prawomocnym wyrokiem, należy wskazać, że wyrok ten po trwającym kilka lat procesie, w związku z zaistniałymi w życiu oskarżonego i jego rodziny, trudnymi do odwrócenia, sytuacjami, nie byłby już tak zadowalający.

Niestety z uwagi na kolejną, omówioną poniżej, nowelizację Kodeksu postępowania karnego uwagi te przybierają postać nieadekwatnych do obecnie obowiązującego stanu prawnego. Niewykluczone jednak, że w przyszłości odzyskają aktualność, co będzie świadczyło o kolejnych, idących w dobrym kierunku, w przeciwieństwie do poniższej, nowelizacjach procedury karnej.

Ostatnia nowelizacja omawianych przepisów weszła w życie 15 kwietnia 2016 r. $^{44}$ Zasadniczym, ogólnym celem przedmiotowej ustawy, jak wskazano w uzasadnieniu

43 W tym kontekście cf. list Rzecznika Praw Obywatelskich Adama Bodnara z dnia 26 października 2015 r., skierowany do ówczesnego Ministra Sprawiedliwości Borysa Budki, znak pisma: II.510.637.2015.MWa; https://www.rpo.gov.pl/sites/default/files/Do_MS_ws_nowych_zasad_ przyznawania_odszkodowania_za_niesluszne_tymczasowe_aresztowanie.pdf[dostęp: 15.04. 2016 r.].

44 Ustawa z dnia 11 marca 2016 r. o zmianie ustawy - Kodeks postępowania karnego oraz niektórych innych ustaw, Dz.U. poz. 437. 
projektu ${ }^{45}$, była modyfikacja modelu postępowania karnego w kierunku przywrócenia aktywniejszej roli sądu w toku procesu oraz nadrzędność zasady prawdy materialnej, gdzie kontradyktoryjność stanowi tylko jedną z zasad procesu, która ułatwia dotarcie do prawdy. W kontekście omawianych zagadnień należy zauważyć, że przedmiotowa nowelizacja modyfikuje treść art. 552 k.p.k. poprzez całkowity powrót do stanu prawnego obowiązującego w okresie od 1 lipca 2003 r. do 30 czerwca 2015 r. Ponadto ustawa ta uchyla (sic') art. 552a i art. 552b. W konsekwencji uchylony został również przepis art. 553 $\S 2$ k.p.k., przy czym treść art. 553 k.p.k. została istotnie zmodyfikowana w odniesieniu do pozostałych jego zapisów. Ustawodawca powrócił również do tytułu rozdziału, który obowiązywał do dnia 30 czerwca 2015 r. Jak słusznie wskazuje W. Jasiński ${ }^{46}$, tytuł ten nie oddaje całokształtu problematyki, której dotyczy rozdział 58 k.p.k. Pomija bowiem, jakże istotną, kwestię orzekania zadośćuczynienia czy też niesłusznego zastosowania środka zabezpieczającego. Powyższa uwaga dotyczy również stanu prawnego obowiązującego od dnia 15 kwietnia $2016 \mathrm{r}$.

Zgodnie $\mathrm{z}$ treścią wskazanej nowelizacji ustawodawca wyeliminował m.in. przepisy dotyczące możliwości dochodzenia odszkodowania i zadośćuczynienia od Skarbu Państwa za niesłuszne stosowanie środków przymusu, w tym zabezpieczenia majątkowego.

W kontekście faktycznego cofnięcia reformy, która weszła w życie 1 lipca 2015 r., przez wskazaną wyżej nowelizację, zdziwienie i niepokój budzi fakt braku szerszego odniesienia się do tych zmian w uzasadnieniu projektu ustawy z dnia 11 marca $2016 \mathrm{r}$. W uzasadnieniu tym, w kontekście omawianej nowelizacji, znalazł się tylko jednozdaniowy zapis: „Postuluje się także powrót do obowiązujących przed dniem 1 lipca 2015 r. regulacji dotyczących odszkodowania za niesłuszne skazanie, tymczasowe aresztowanie lub zatrzymanie (rozdział 58 k.p.k.)”47. Niestety ustawodawca w żaden sposób nie uzasadnił swojego stanowiska, uniemożliwiając tym samym polemikę $\mathrm{z}$ argumentacją, którą kierował się, zmieniając przedmiotowe zapisy.

Niemniej zmiany w zakresie rozdziału 58 k.p.k., które weszły w życie 15 kwietnia 2016 r., zasługują na najwyższą krytykę i to z kilku względów. Przede wszystkim cofnięto przepisy, wprowadzone przecież w oparciu o liczne postulaty doktryny ${ }^{48}$, które słusznie poszerzały katalog środków przymusu, w tym o zabezpieczenie majątkowe, których niezasadne stosowanie mogło skutkować wystąpieniem z roszczeniami o odszkodowanie i zadośćuczynienie. Wprowadzona nowelizacja zamknęła zatem m.in. możliwość pociągnięcia państwa do odpowiedzialności, na gruncie procesu karnego, za niesłuszne stoso-

45 Uzasadnienie projektu ustawy o zmianie ustawy - Kodeks postępowania karnego oraz niektórych innych ustaw, https://legislacja.rcl.gov.pl/docs//2/12280750/12331664/12331665/dokument204113.pdf, http://www.sejm.gov.pl/sejm8.nsf/druk.xsp?nr=207 [dostęp: 10.04.2016], s. 1-2.

46 W. Jasiński, op. cit., s. 53-54.

47 Uzasadnienie projektu ustawy z dnia 11 marca 2016 r., op. cit., s. 16.

48 Cf. literatura wskazana we wcześniejszych częściach artykułu. 
wanie zabezpieczenia majątkowego. $Z$ racjonalnością takiej zmiany trudno się zgodzić, tym bardziej że głównym jej powodem, jak można przypuszczać, było nieproporcjonalne obciążanie finansowe Skarbu Państwa ${ }^{49}$. Zastosowanie zabezpieczenia majątkowego może bez wątpienia powodować dla oskarżonego różnego rodzaju szkody majątkowe i niemajątkowe. Mimo że nie pozbawia oskarżonego własności, to czasowo uniemożliwia rozporządzanie rzeczą. Regulacja dająca sposobność rozliczenia państwa, na podstawie przepisów postępowania karnego, za niesłuszne zastosowanie tego środka wydaje się zatem oczywista.

Jak słusznie wskazano w opinii Ośrodka Badań, Studiów i Legislacji Krajowej Rady Radców Prawnych ${ }^{50}$, dokonane omawianą nowelizacją zmiany przede wszystkim należy uznać za przedwczesne. Wprowadzonych ustawą z 2013 r. przepisów, z uwagi na niezwykle krótki czas obowiązywania, nie sposób ocenić z punktu widzenia praktyki. Pozwoliłoby to natomiast na zdiagnozowanie rzeczywistych problemów powstałych na gruncie stosowania stanu prawnego obowiązującego od 1 lipca 2015 r. i wyciągnięcie rzetelnych wniosków. Bez takiej oceny wycofywanie wprowadzonych zmian jest po prostu nieracjonalne i wprowadza zamęt w zakresie obowiązującego prawa.

Ponadto należy wskazać, że przedmiotowe zmiany zostały ocenione, co do zasady, negatywnie również przez Krajową Radę Sądownictwa ${ }^{51}$ oraz Biuro Analiz Sejmowych Kancelarii Sejmu ${ }^{52}$. Prezydium Krajowej Rady Sądownictwa krytycznie zaopiniowało nie tylko same przepisy, ale także sposób ich wprowadzenia. Mianowicie poważne zastrzeżenia wzbudził sposób i tryb prowadzenia prac legislacyjnych przedmiotowego projektu, który z uwagi na zakres proponowanych zmian oraz rangę i znaczenie tych przepisów dla ogólu obywateli powinien być procedowany z zachowaniem właściwych standardów. Krajowa Rada Sądownictwa wskazała, że tego rodzaju prace legislacyjne powinny być przede wszystkim poprzedzone stanowiskiem Komisji Kodyfikacyjnej Prawa Karnego, co nie miało miejsca.

49 Taki argument przedstawiano w doktrynie, krytykując nowelizację wprowadzoną ustawą z 2013 r. Cf. m.in. B. Mik, op. cit., s. 57-58; P. Czarnecki, op. cit., s. 70-71.

50 Opinia dotycząca projektu ustawy o zmianie ustawy-Kodeks postępowania karnego orazniektórych innych ustaw (druk sejmowy nr 207), http://kirp.pl/wp-content/uploads/2016/02/opiniaOBSiL-w-sprawie-projektu-ustawy-o-zmianie-ustawy-Kodeks-post\%C4\%99powaniakarnego-oraz-niekt\%C3\%B3rych-innych-ustaw-1.pdf [dostęp: 15.04.2016].

51 Cf. stanowisko Prezydium Krajowej Rady Sądownictwa z 8 lutego 2016 r. dotyczące projektu zmiany ustawy - Kodeks postępowania karnego oraz niektórych innych ustaw (druk sejmowy nr 207 z 27 stycznia 2016 r.),http://krs.pl/p1/aktualnosci/d,2016,2/3944,stanowisko-prezydiumkrajowej-rady-sadownictwa-z-8-lutego-2016-r-dotyczace-projektu-zmiany-ustawy-kodekspostepowania-karnego-oraz-niektorych-innych-ustaw-druk-sejmowy-nr-207-z-27-stycznia2016-r [dostęp: 15.04.2016].

52 A. Sakowicz, Opinia prawna na temat projektu ustawy o zmianie ustawy - Kodeks postepowania karnego oraz niektórych innych ustaw (druk sejmowy nr 207) z 22 lutego 2016 r., http://www.sejm. gov.pl/ [dostęp: 3.03.2016]. 
Podsumowując powyższe rozważania, należy wskazać, że możliwość popełnienia błędu przez organ stosujący prawo istnieje właściwie zawsze. Konsekwencją jest tu podjęcie niewłaściwej decyzji ${ }^{53}$. Ustawodawca, będąc świadomy tego faktu, powinien przewidzieć przepisy umożliwiające $\mathrm{w}$ pełni dochodzenie odpowiedzialności państwa za wydanie błędnych orzeczeń. W procesie regulacji zmian Kodeksu postępowania karnego miała natomiast miejsce sytuacja nie do przyjęcia. Najpierw ustawodawca wprowadził przepisy znacznie rozszerzające dotychczasową odpowiedzialność Skarbu Państwa, następnie, po niespełna dziesięciu miesiącach obowiązywania, je wycofał. Przy czym nie dość, że pominięto w tym zakresie opinię Komisji Kodyfikacyjnej Prawa Karnego, to w ogóle nie wzięto pod uwagę negatywnych opinii innych podmiotów, takich jak Krajowa Rada Sądownictwa. Na szczególną krytykę zasługuje ponadto niezwykle skrótowe odniesienie się przez ustawodawcę do wprowadzonych zmian w uzasadnieniu projektu. Właściwie nie wiadomo dlaczego omawiana regulacja, dotycząca chociażby odpowiedzialności Skarbu Państwa za niesłuszne stosowanie środków przymusu, została usunięta. Ustawodawca de facto nie dał nawet sposobności jej oceny, gdyż w tak krótkim okresie obowiązywania nie miała szans przedstawić swych uwag i komentarzy ani doktryna, ani judykatura. Nie wiadomo więc, jak zderegulowane przepisy funkcjonowały i czy okazałyby się przydatne w przyszłości. Takie działania ustawodawcy zasługują na najwyższą krytykę, gdyż konieczność prawnokarnej ochrony osób, wobec których niesłusznie zastosowano środek przymusu, w tym zabezpieczenie majątkowe, uderzające $\mathrm{w}$ jedną $\mathrm{z}$ delikatniejszych sfer, jaką jest prawo własności, jest w mojej ocenie niezaprzeczalna.

Zgodnie z zasadą stabilności prawa zmieniać należy tylko takie rozwiązania legislacyjne, których stosowanie jest niefunkcjonalne lub prowadzi do powstania niespójności, luk czy wątpliwości interpretacyjnych ${ }^{54}$. Pogwałcenie jej w zakresie przedstawionej w niniejszym artykule regulacji jest więc oczywiste, co w demokratycznym państwie prawa jest nie do przyjęcia.

\section{Literatura}

Banaszak B., Konstytucja Rzeczypospolitej Polskiej. Komentarz, Warszawa 2012.

Boratyńska K.T., Chojniak Ł., Jasiński W., Postepowanie karne, Warszawa 2015.

Chojniak Ł., Odszkodowanie za niestuszne skazanie, tymczasowe aresztowanie lub zatrzymanie, Warszawa 2013.

Chojniak Ł., Odszkodowanie za niestuszne skazanie w polskim procesie karnym - wybrane zagadnienia, [w:] Węztowe problemy procesu karnego, red. P. Hofmański, Warszawa 2010.

53 P. Czarnecki, op. cit., s. 55.

54 Ibidem, s. 72-73. 
244 | Adam Mickiewicz University Law Review

Cioch P., Odpowiedzialnośc Skarbu Państwa z tytutu niestusznego skazania, Warszawa 2007.

Czarnecki P., Odpowiedzialnośc Skarbu Państwa za btędy wymiaru sprawiedliwości w sprawach karnych po 1 lipca 2015 r., „Internetowy Przegląd Prawniczy TBSP UJ”2015, nr 2.

Dąbkiewicz K., Kodeks postępowania karnego. Komentarz do zmian, Warszawa 2015.

Garlicki L., Komentarz do art. 77 Konstytucji, [w:] Konstytucja Rzeczypospolitej Polskiej. Komentarz, red. L. Garlicki, t. 5, Warszawa 2007.

Grajewski J., Przebieg procesu karnego, Warszawa 2004.

Haczkowska M., Środki ochrony wolności i praw, [w:] Komentarz. Konstytucja Rzeczypospolitej Polskiej, red. M. Haczkowska, Warszawa 2014.

Hofmański P., Nowe oblicze środków przymusu w procesie karnym, „Białostockie Studia Prawnicze"1992, nr 1.

Hofmański P., Problem odpowiedzialności państwa za szkody spowodowane środkami przymusu w procesie karnym, [w:] Stosowanie środków przymusu w procesie karnym. Problem karnoprocesowych ograniczeń praw obywatelskich, red. K. Amelung, K. Marszał, Katowice 1990.

Hofmański P., Sadzik E., Zgryzek K., Kodeks postęporwania karnego, t. III, Komentarz do artykutów 468-682, Warszawa 2012.

Jasiński W., Komentarz do rozdziatu 58 k.p.k., [w:] Kodeks postępowania karnego. Komentarz, red. J. Skorupka, Warszawa 2015.

Jasiński W., Odszkodowanie i zadośuczynienie za niestuszne skazanie, wykonanie środka zabezpieczajacego oraz niezasadne stosowanie środków przymusu po nowelizacji kodeksu postępowania karnego, „Prokuratura i Prawo”2015, nr 9.

Kosik J., Zasady odpowiedzialności państwa za szkody wyrzq̨dzone przez funkcjonariuszów, Wrocław 1961.

Mik B., O potrzebie dodatkowego, szczególnego unormowania odpowiedzialności odszkodowawczej Skarbu Państwa za niestuszne skazanie oraz niewątpliwie niestuszne oskarżenie, przedstawienie zarzutów lub zastosowanie nieizolacyjnego środka zapobiegawczego, „Prokuratura i Prawo" 2012, nr 12.

Paprzycki L.K., Komentarz do rozdziatu 58 k.p.k., [w:] Kodeks postepowania karnego, t. II, Komentarz do art. 425-673, red. L.K. Paprzycki, Warszawa 2013.

Sakowicz A., Opinia prawna na temat projektu ustawy o zmianie ustawy - Kodeks postepowania karnego oraz niektórych innych ustaw (druk sejmowy nr 207) z 22 lutego 2016 r., http://www.sejm.gov.pl/ [dostęp: 3.03.2016].

Skrzydło W., Konstytucja Rzeczypospolitej Polskiej. Komentarz, Warszawa 2013.

Stefański R.A., Odpowiedzialność za niestuszne skazanie, niewątpliwie niestuszne oskarżenie, przedstawienie zarzutów lub zastosowanie nieizolacyjnego środka zapobiegawczego, „Prokuratura i Prawo” 2012, nr 12.

Szpunar A., Odpowiedzialnośc Skarbu Państwa za funkcjonariuszy, Warszawa 1985. 
Świecki D., Komentarz do rozdziatu 58 k.p.k., [w:] Kodeks postępowania karnego. Komentarz, t. II, red. D. Świecki, Warszawa 2015.

Tęcza-Paciorek A.M., O potrzebie uregulowania odszkodowania za niestuszne oskarżenie, „Przegląd Sądowy” 2011, nr 2.

Tęcza-Paciorek A.M., Zasada domniemania niewinności w polskim procesie karnym, Warszawa 2012.

Wiliński P., Proces karny w świetle Konstytucji, Warszawa 2011.

Konstytucja RP z dnia 2 kwietnia 1997 r., Dz.U. nr 78 poz. 486.

List Rzecznika Praw Obywatelskich Adama Bodnara z dnia 26 października 2015 r., skierowany do ówczesnego Ministra Sprawiedliwości Borysa Budki, znak pisma: II.510. 637.2015.MWa; https://www.rpo.gov.pl/sites/default/files/Do_MS_ws_nowych_zasad_przyznawania_odszkodowania_za_niesluszne_tymczasowe_aresztowanie.pdf [dostęp: 15.04.2016].

Opinia dotycząca projektu ustawy o zmianie ustawy - Kodeks postępowania karnego oraz niektórych innych ustaw (druk sejmowy $\mathrm{nr}$ 207), http://kirp.pl/wp-content/ uploads/2016/02/opinia-OBSiL-w-sprawie-projektu-ustawy-o-zmianie-ustawyKodeks-post $\%$ C4\%99powania-karnego-oraz-niekt\%C3\%B3rych-innych-ustaw-1. pdf [dostęp: 15.04.2016].

Stanowisko Prezydium Krajowej Rady Sądownictwa z 8 lutego 2016 r. dotyczące projektu zmiany ustawy - Kodeks postępowania karnego oraz niektórych innych ustaw (druk sejmowy nr 207 z 27 stycznia 2016 r.), http://krs.pl/pl/aktualnosci/d,2016,2/3944,stanowisko-prezydium-krajowej-rady-sadownictwa-z-8-lutego-2016-r-dotyczaceprojektu-zmiany-ustawy-kodeks-postepowania-karnego-oraz-niektorych-innychustaw-druk-sejmowy-nr-207-z-27-stycznia-2016-r [dostęp: 15.04.2016].

Ustawa z dnia 6 czerwca 1997 r. - Kodeks postępowania karnego, Dz.U. nr 89 poz. 555 z późn. zm.

Ustawa z dnia 27 września 2013 r. o zmianie ustawy - Kodeks postępowania karnego oraz niektórych innych ustaw, Dz.U. poz. 1247.

Ustawa z dnia 20 lutego 2015 r. o zmianie ustawy - Kodeks karny oraz niektórych innych ustaw, Dz.U. poz. 396.

Ustawa z dnia 11 marca 2016 r. o zmianie ustawy - Kodeks postępowania karnego oraz niektórych innych ustaw, Dz.U. poz. 437.

Uzasadnienie Komisji Kodyfikacyjnej Prawa Karnego projektu ustawy o zmianie ustawy Kodeks postępowania karnego i niektórych innych ustaw, https://bip.ms.gov.p1/p1/ projekty-aktow-prawnych/prawo-karne/ [dostęp: 1.04.2016].

Uzasadnienie projektu ustawy o zmianie ustawy - Kodeks postępowania karnego oraz niektórych innych ustaw,https://legislacja.rcl.gov.pl/docs//2/12280750/12331664/1233 
246 | Adam Mickiewicz University Law Review

1665/dokument204113.pdf, http://www.sejm.gov.pl/sejm8.nsf/druk.xsp?nr=207 [dostęp: 10.04.2016].

Wyrok TK z dnia 4 grudnia 2001 r., SK 18/00, OTK 2001, nr 8, poz. 256.

Wyrok TK z dnia 20 stycznia 2004 r., SK 26/03, OTK-A 2004, nr 1, poz. 3.

Wyrok SA w Katowicach z dnia 3 lipca 2015 r., II Aka 220/15, „Prokuratura i Prawo” 2016, nr 3, poz. 36 .

\section{SUMMARY}

The assessment of a legislator's actions under the provisions of the Criminal Procedure Code concerning compensation for unjustifiable use of coercive measures, with particular emphasis on seizure of property

Recently, amendments to the Criminal Procedure Code have been made with unusual frequency. On 1 July 2015, the provisions which made a fundamental remodeling of the criminal procedure came into force. These included innovative regulations for the possibility of applying for compensation from the State Treasury for unjustifiable use of coercive measures, including seizure of property. Although the implementation of these provisions was consistent with the standpoint of the majority of the doctrine, they were only in force for less than ten months. In the motives of the bill, which had removed them from the Code, there was actually no justification for such actions of the legislator. Because they were in force for such a short duration, there is no possibility of assessing their functioning. Such actions of the legislator deserve the highest criticism, because there is an undeniable need to protect persons against whom coercive measures, including seizure of property, were unjustifiably applied.

Keywords: damages, compensation, coercive measures, seizure of property, amendment to the Criminal Procedure Code

Martyna Ostrzycka, Adam Mickiewicz University Poznań, Faculty of Law and Administration, Al. Niepodległości 53, 61-714 Poznań, e-mail: martyna.ostrzycka@amu. edu.pl. 